
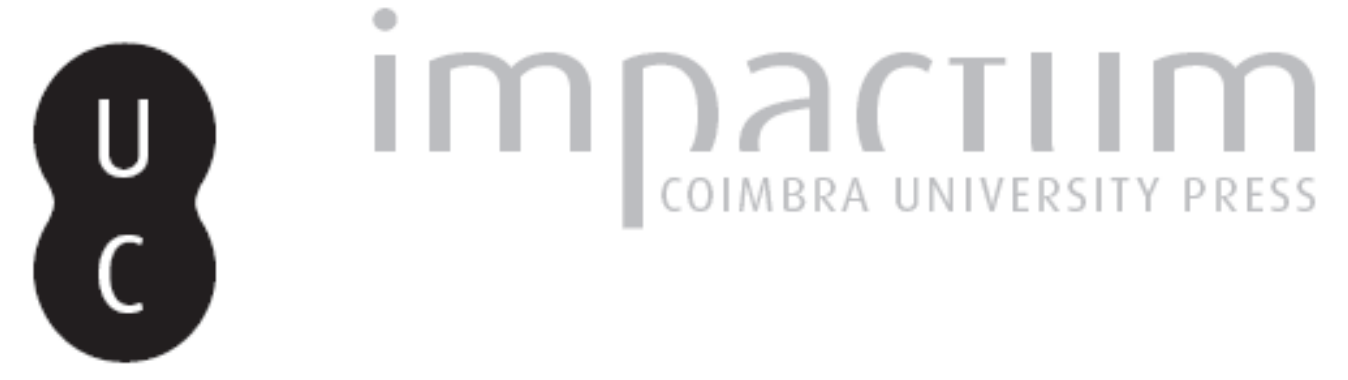

Percursos de vida: as potencialidades da micro-história e das pesquisas biográficas

Autor(es): Durães, Margarida

Publicado por: Centro de História da Sociedade e da Cultura

URL persistente:

URI:http://hdl.handle.net/10316.2/39531

DOI:

DOI:http://dx.doi.org/10.14195/1645-2259_10-2_5

Accessed : $\quad$ 26-Apr-2023 14:17:11

A navegação consulta e descarregamento dos títulos inseridos nas Bibliotecas Digitais UC Digitalis, UC Pombalina e UC Impactum, pressupõem a aceitação plena e sem reservas dos Termos e Condições de Uso destas Bibliotecas Digitais, disponíveis em https://digitalis.uc.pt/pt-pt/termos.

Conforme exposto nos referidos Termos e Condições de Uso, o descarregamento de títulos de acesso restrito requer uma licença válida de autorização devendo o utilizador aceder ao(s) documento(s) a partir de um endereço de IP da instituição detentora da supramencionada licença.

Ao utilizador é apenas permitido o descarregamento para uso pessoal, pelo que o emprego do(s) título(s) descarregado(s) para outro fim, designadamente comercial, carece de autorização do respetivo autor ou editor da obra.

Na medida em que todas as obras da UC Digitalis se encontram protegidas pelo Código do Direito de Autor e Direitos Conexos e demais legislação aplicável, toda a cópia, parcial ou total, deste documento, nos casos em que é legalmente admitida, deverá conter ou fazer-se acompanhar por este aviso.

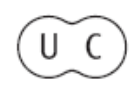




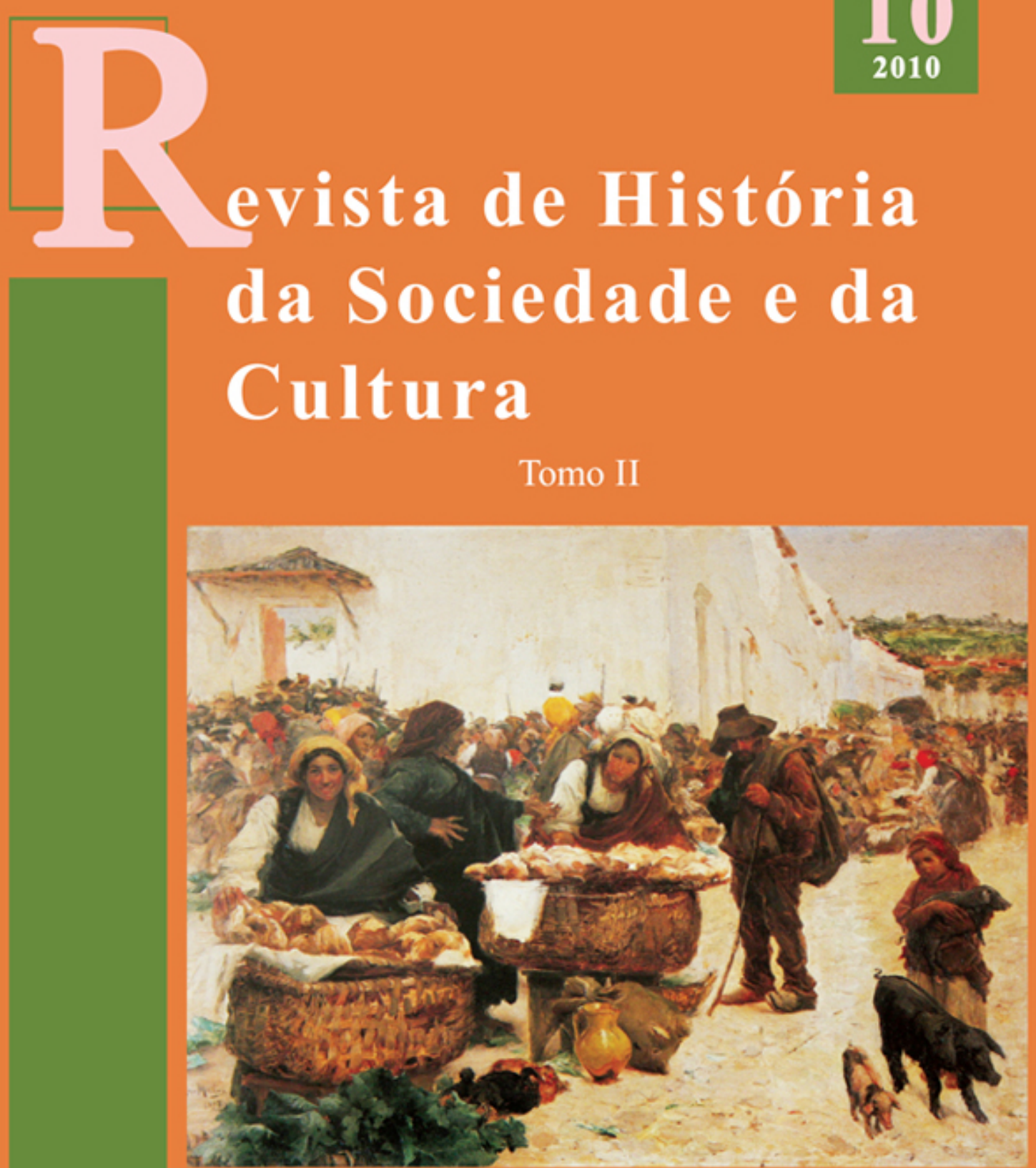

Centro de História da Sociedade e da Cultura Universidade de Coimbra

Coimbra 


\title{
Percursos de vida. As potencialidades da micro-história e das pesquisas biográficas
}

\author{
Margarida Durães \\ Departamento de História, Instituto de Ciências Sociais, Universidade do Minho \\ margaridad@ics.uminho.pt \\ Texto recebido em/ Text submitted on: 25/02/2010 \\ Texto aprovado em/ Text approved on: 01/05/2010
}

\section{Resumo/Abstract:}

Este texto tem como objectivo conhecer alguns aspectos que qualificam os comportamentos dos negociantes inseridos nas comunidades camponesas. Transformando-se em intermediários privilegiados, entre as economias do mundo rural e do mundo urbano, os negociantes desenvolveram estratégias comerciais que possibilitaram a utilização, em seu benefício, da dependência dos camponeses na venda dos excedentes agrícolas. Partindo de um estudo de caso e utilizando os procedimentos da micro-história, estudou-se um espólio documental privado - produzido por um jovem negociante estabelecido, aos 22 anos de idade, na freguesia de Paderne, concelho de Melgaço, junto da fronteira luso-galaica - de onde foram retiradas informações que cruzadas com os conteúdos de outras fontes - registos paroquiais e, sobretudo, os livros de notas dos tabeliães e os recenseamentos eleitorais permitiram conhecer o seu percurso de vida bem como o conjunto de estratégias que levou a cabo para intensificar a actividade comercial e obter o reconhecimento dos seus pares e da sociedade onde se introduziu. O estudo desenvolve uma narrativa do "individual" que analisa um percurso de vida. Porém, a inserção das estratégias, pessoais e familiares deste negociante, no contexto socioeconómico e político da região, possibilitarão o conhecimento do modelo cultural dos homens de negócio.

This paper envisages analysing some features of the behaviour of traders in farming communities. As privileged intermediaries of rural and urban economies, traders developed commercial strategies for using to their advantage farmers' dependence on sales of excess produce. Based on a case-study and using micro-history procedures, we analysed private documents - produced by a young merchant - 22 years old - who established in Paderne, municipality of Melgaço, on the Portuguese-Galician border. The information drawn from this source, compared with that of other sources - parish records and, particularly, notaries' books and electoral censuses- unveils the merchant's path in life and the strategies he adopted to enhance trade and earn the recognition of his peers and the surrounding society. The study develops a narrative of 'individual', based on the analysis of a life. However, the contextualization of this merchant's personal and family strategies against the region's social and economic backdrop provides insight into the cultural model of businessmen.

Palavras chave/Keywords:

Negociante; Crédito; Proprietário; Escrivão; Contribuinte.

Merchant; Credit; Owner; Registrar; Tax-Payer. 


\section{Introdução}

Custódio Jozé Gomes de Villasboas, memorialista do final do século XVIII, sustentava que qualquer aldeia ou freguesia do Alto-Minho possuía uma sociedade organizada em quatro grupos, apresentando-se cada um deles, em relação aos demais, numa proporção que permitia a sustentabilidade da comunidade rural e o equilíbrio da sua funcionalidade. Segundo o autor, os quatro grupos (jornaleiros, caseiros, lavradores-artesãos e lavradores-proprietários) distribuíam-se de modo equilibrado em relação à disponibilidade dos terrenos agricultáveis e às necessidades de mão-de-obra para as distintas tarefas da comunidade rural ${ }^{1}$.

Alguns anos depois, na década de cinquenta do século XIX, a estratificação social e a relativa proporcionalidade entre os distintos grupos pareciam manter-se idênticas já que, Eusébio Furtado Coelho, outro analista da mesma região, apontava, nas suas Estatísticas do distrito de Viana do Castelo, uma proporção de 2,8 trabalhadores para cada proprietário-lavrador, justificando, deste modo, os baixos salários praticados nesta região ${ }^{2}$. Outro meio século mais à frente, no final do século XIX, início do século XX, Bazilio Telles, reafirmava a mesma realidade ${ }^{3}$, dando a entender que ao longo deste largo período nada tinha mudado na organização socioeconómica das comunidades rurais minhotas. Os processos de cultivo eram os mesmos desde tempos ancestrais continuando a assentar no amanho intensivo dos terrenos agricultáveis, sem recurso a meios tecnológicos em virtude destes serem substituídos pela abundante mão-de-obra da região. Deste sistema resultava uma agricultura de baixa produtividade e pouco rentável que se dirigia, sobretudo, para a satisfação alimentar do cultivador e da sua família.

A imagem de um mundo imóvel, cauteloso e conservador foi a opinião corrente, divulgada por diferentes estudos provenientes de distintas áreas científicas, apesar de serem conhecidas as profundas mudanças verificadas nas sociedades camponesas ao longo dos séculos. Defendia-se a resistência

1 SOUSA, Fernando de e ALVES, Jorge Fernandes - Alto Minho. População e Economia nos Finais do Setecentos. Lisboa: Editorial Presença, 1997.

2 COELHO, Eusébio Furtado - Estatísticas do Distrito de Vianna do Castello. Lisboa: Imprensa Nacional, 1861.

3 TELLES, Bazilio - Carestia da Vida nos Campos. Porto: Chardron, 1903, p. 239. 
e adaptação das sociedades rurais às novidades que lhes eram introduzidas "pela acção de forças totalmente externas"4.

Todavia, a estas análises, defensoras do imobilismo e conservadorismo das sociedades camponesas, contrapõem-se outros estudos onde nos é dado a conhecer um mundo rural muito mais complexo - composto por outros grupos além dos que trabalham e vivem directamente da exploração da terra -, tradicionalmente agitado, díspar e conflituoso do ponto de vista social e muito activo do ponto de vista económico e político 5 .

Assim, o que propomos no presente texto - que faz parte de um projecto de investigação mais alargado que pretende conhecer o papel dos homens de negócio sediados nas sociedades rurais com o objectivo de aceder às lógicas comerciais, às estratégias desenvolvidas e aos modelos culturais adoptados para a sua instalação e organização das suas casas - é a "redução da escala de análise" como é proposto pela micro-história, a fim de nos aproximarmos e compreendermos a complexa realidade das sociedades rurais ${ }^{6}$. Como em outros trabalhos históricos que utilizaram esta abordagem, o presente estudo também se "centra nas estratégias individuais e familiares" . À procura de "indícios", privilegiamos os "acontecimentos minúsculos" como a compra, venda e arrendamento de terras, a compra e venda de gado, os movimentos do crédito e a luta pelo prestígio e pelo reconhecimento. Enfim, tentamos encetar o nosso trabalho pelo "rés-do-chão", como nos é proposto na expressão paradigmática de Jacques Revel ao caracterizar os procedimentos da micro-história ${ }^{8}$.

4 Em relação às questões ligadas ao conservadorismo das sociedades camponesas minhotas cf. SILVA, Manuel Carlos Ferreira da-Resistir e Adaptar-se. Constrangimentos e estratégias camponesas no Noroeste de Portugal. Porto: Afrontamento, 1998. Para o contexto europeu conhecer a posição de LEVI, Giovanni - A Herança Imaterial. Trajectória de um exorcista no Piemonte do século XVII. Rio de Janeiro: Civilização Brasileira, 2000, p. 43.

5 DURÃES, Margarida - Espírito de aventura ou aperto da vida? As migrações internas e os seus impactos na organização familiar e social das comunidades rurais do Alto Minho (sécs. XVIII-XIX), Estudos Regionais, série nº 3, 2009, p. 117-145; Cf. ainda ROSENTHAL, Paul-André - Les sentiers invisibles. Espaces, familles et migrations dans la France du $19^{e}$ siècle. Paris: EHESS, 1999.

6 LIMA, Henrique Espada-A micro-história italiana. Escalas, indícios e singularidades. Rio de Janeiro: Civilização Brasileira, 2006, p. 225-245.

7 LEVI, Giovanni - A Herança Imaterial..., cit., p. 45.

8 REVEL, Jacques - Prefácio: A História ao Rés-do-Chão in LEVI, Giovanni, A Herança Imaterial..., cit., p. 19-25. 
A investigação inicia-se em torno de um indivíduo - António, negociante - porque, como defende Carlo Ginzburg, "alguns estudos biográficos mostraram que um indivíduo medíocre, destituído de interesse por si mesmo - e justamente por isso representativo - pode ser pesquisado como se fosse um microcosmo de um estrato social inteiro num determinado período histórico"9.

Para acedermos a esta realidade microscópica utilizaremos o teor do espólio documental que, só por casualidade, este anónimo homem de negócios nos legou avaliando qual o interesse das notas e registos inseridos nos seus Livros de Razão para o relato da história da sua vida privada mas, também, para a história social da região. A vida do negociante António Luís Pereira permitirá aceder à "banalidade e normalidade" das relações sociais, das regras económicas e da vida política de um lugarejo desconhecido e perdido no sopé das serranias do Alto Minho, bem junto da fronteira luso-galaica. Por fim, cruzando as informações veiculadas pelos Livros de Razão de António com as informações recolhidas nos Livros de Notas dos tabeliães da região e com as listas dos Recenseamentos Eleitorais, daremos conta de algumas das estratégias económicas e sociais que António utilizou para o estabelecimento da sua casa, para a conquista de prestígio e para a sua interacção na comunidade onde se estabeleceu ${ }^{10}$.

\section{As fontes}

Não sabemos quando é que António Luís Pereira se terá instalado com a sua loja de comércio na freguesia de Paderne, do concelho de Melgaço. Mas, em 1837, adquire um pequeno livro no qual lança, na primeira página, uma declaração de intenção onde exprime a serventia que o livro teria:

9 GINZBURG, Carlo - O queijo e os vermes. O cotidiano e as ideias de um moleiro perseguido pela Inquisição. S. Paulo: Companhia das Letras, 1987, p. 27.

${ }^{10}$ Este texto foi produzido no âmbito do projecto de investigação PTDC/HAH/71309/2006, financiado pela FCT e intitulado "Portas adentro: modos de habitar do séc. XVI e XVIII em Portugal". 
"Livro que há de servir para nelle carregar os gados que tenho ao ganho, títulos a juro de que sou direito senhor eu António Luis Pereira - juntamente os assentos das terras que compro"

Escreveu com letra firme, bem desenhada, na primeira pessoa do singular, utilizando o estilo do tabelionado de modo a afirmar o poder de assinante e, sobretudo, conferindo valor e autenticidade a todas as informações que ali foram registadas. Para reforçar a veracidade de tudo quanto foi anotado no livro, António assinou com um sinal público de extraordinária beleza onde o A e o L se entrelaçam contornados de arabescos que só ele sabia desenhar.

Com este livro dava-se início a um conjunto de 9 Livros de Razão, onde o comerciante se preocupou em registar o movimento de duas das suas actividades comerciais: "o gado ao ganho" e o dinheiro emprestado a juros. A estes dois assuntos que surgem como as principais actividades na preocupação dos registos, António Luís Pereira acrescentou nas suas anotações um terceiro tema: o livro também serviria para "assentar" as terras que ele tinha intenção de comprar ${ }^{11}$.

Faltava, no entanto, a este conjunto de Livros de Razão o movimento das compras e vendas da loja. Como tantos outros comerciantes instalados nas aldeias, António tinha como principal função assegurar as indispensáveis relações desta localidade com o mundo exterior ${ }^{12}$. Nessa medida pareceu-nos, à primeira vista, estar perante uma documentação que nos fornecia uma informação parcelar dos negócios desenvolvidos pelo negociante. Todavia, após uma observação mais atenta do conteúdo dos diferentes livros que tínhamos em mãos, verificamos que, apesar do empréstimo do dinheiro a juros e o negócio do "gado ao ganho" terem a primazia na informação

${ }^{11}$ Estes livros não provêm de um depósito de arquivos públicos. Eles fazem parte de um pequeno espólio privado pertencente aos descendentes de António Luís Pereira e constituem um dos elementos do património e memória familiar. $\mathrm{O}$ acaso permitiu-nos o acesso a esta documentação, tendo-nos sido concedido o privilégio de a consultar e estudar. Ao longo deste estudo, sempre que utilizarmos a informação extraída de algum destes livros será indicada como pertencente ao Arquivo Privado da Família Pereira (APFP).

${ }^{12}$ MICHEL, Louis - Un marchand rural en Nouvelle-France. François-Augustin Bailly de Messin (1709-1711). Revue d'histoire de l'Amérique-Française. 33, nº 2 (1979) 215-262. JUSTINO, David - A Formação do Espaço Económico Nacional. Portugal 1810-1913. Lisboa: Ed. Vega, vol. I, 1988, p. 224-272. 
registada, era também possível aceder à proveniência de alguns produtos que abasteciam a loja, à origem, composição e gestão do património imóvel que o comerciante foi adquirindo ao longo dos anos, sendo ainda possível encontrar aqui e ali, apontamentos de carácter mais particular que diziam respeito a despesas com obras de melhoramentos de alguns prédios, tentativas de desenvolvimento de outros negócios e pequenas questões de carácter familiar.

A partir de então, fomos confrontados com a necessidade de definir a tipologia desta documentação e determinar o valor histórico das suas informações. Como classificar os livros nos quais aquele, que nos parecia ser um pequeno negociante de aldeia, foi lançando, ao longo de uma vida de negócios muito activa, um conjunto de notas por ele consideradas da máxima importância?

Tudo indicava que estávamos perante um conjunto de Livros de Razão. Porém, na opinião de Roland Mousnier um Livro de Razão completo deve conter três partes: "a primeira dedica-se à história da família, à sua genealogia, aos parentes, às alianças, aos casamentos, aos nascimentos dos filhos e aos óbitos. Em segundo lugar, deve conter tudo o que concerne o património e a gestão dos bens, as receitas, as despesas, as economias, os investimentos. Em último lugar, este tipo de documentação deve conter os conselhos, os costumes, a conduta, enfim os princípios fundamentais em relação a Deus, ao próximo, à família e a si mesmo"13. Na mesma linha, Jean Tricard distingue os Livros de Razão de outras fontes que pertencem a géneros vizinhos como os diários, as crónicas, as memórias ou as autobiografias, porque, segundo o autor, os "Livros de Razão associam a contabilidade dos bens com a contabilidade dos membros da família, ou seja, dão informações patrimoniais e informações familiares. São uma espécie de memória contabilística e familiar aplicada aos bens e aos homens"14.

Se adoptássemos qualquer destas definições no seu sentido literal não poderíamos classificar os livros em análise como Livros de Razão já que eles contêm, tão-somente, informações sobre uma parte da actividade comercial

${ }^{13}$ MOUSNIER, Roland - Les institutions de la France sous la Monarchie Absolue (1598-1789), Paris: PUF, Tome 1, 1974, p. 48-49.

${ }^{14}$ TRICARD, Jean - Les livres de raison français au miroir des livres de familles italiens: pour relancer une enquête. Revue historique. 624 (2002) p. 999. 
e da vida económica e material do negociante que os elaborou. Falta-lhes a "história da família" ou "a memória contabilística aplicada aos homens". A reforçar esta ideia, os livros que fazem parte do espólio em análise também não deveriam ser considerados como Livros de Razão, já que no seu conteúdo não poderemos apreender o princípio ou a ideia de linhagem que, segundo Mousnier, deve estar presente na redacção de todos os Livros de Razão. O seu autor era um simples e obscuro comerciante de aldeia e não o membro de uma família da fidalguia minhota preocupado com as origens ancestrais de modo a provar a antiguidade da sua linhagem ${ }^{15}$.

Porém, nem todos os historiadores apresentam uma definição tão completa, nem consideram que a ideia de linhagem seja o princípio identificador dos Livros de Razão. Para Madeleine Foisil "o livro de razão é simplesmente um livro no qual um bom administrador ou um comerciante escreve tudo o que ele recebe e gasta para dar conta a ele próprio de todos os seus negócios" ${ }^{\prime 16}$. Segundo a mesma autora, na maior parte, os Livros de Razão são, à primeira vista, o mais elementar livro de contas podendo, no entanto, surgir exemplares mais desenvolvidos, mais elaborados e com uma maior riqueza e diversidade de informação. Mas, mesmo quando isso se verifica, é sempre à volta das contas que eles se articulam e se constroem. Se aplicarmos esta definição e caracterização à documentação que tínhamos entre mãos, podemos dizer que estamos perante um conjunto de Livros de Razão nos quais, desde a primeira página - no auto de abertura - estão expressos os princípios que devem presidir à gestão de um bom negociante e administrador dos seus bens.

Mau grado as limitações e insuficiências já apontadas, a observação destes Livros de Razão, como passo prévio para a análise que pretendemos levar a cabo, deve revestir-se de prudência e fazer-se atentamente porque o seu conteúdo permite-nos aceder a algumas informações que podem ser consideradas o "embrião vital" para o conhecimento do percurso de vida

${ }^{15}$ As histórias de vida do homem comum foram valorizadas pela actual historiografia em virtude do papel que assumem no acesso ao conhecimento da massa anónima que ajudou a construir a história de um povo. Cf. DOSSE, François - Le Pari Biographique. Écrire une vie. Paris: Ed. La Découverte, 2005, p. 327-337.

${ }^{16}$ FOISIL, Madeleine - Escritos de foro privado in ARIÉS, Philippe e DUBY, Georges (dir) - História da Vida Privada. Porto: Ed. Afrontamento, 1990, vol. 3, p. 332. 
deste negociante e das redes familiares, sociais e políticas por ele entretecidas visando a sua valorização, a obtenção de prestígio e o seu reconhecimento pela comunidade onde se tinha inserido. Juntamente com a análise das grandes rubricas - dinheiro a juro, gado ao ganho, compra de terras devemos estar atentos às pequenas anotações, aos inúmeros papeis (recados e mensagens) e cartas que foram guardados no interior das páginas destes livros. Cruzar toda esta informação com outras fontes - arquivos notariais, registos paroquiais e recenseamentos eleitorais - tornou-se necessário não só para colmatar lacunas como também para lhes dar um sentido mais lato que pudesse ultrapassar a simples contabilidade ou a riqueza material de um indivíduo.

\section{De negociante a proprietário e senhorio}

A novidade que representam as abordagens das questões sociais e culturais através dos procedimentos da micro-história e a riqueza de informações que é possível extrair a partir dos Livros de Razão transformou-se num desafio. O indivíduo - António - e a reconstituição do seu percurso de vida, em geral inacessível às outras abordagens historiográficas, tornaram-se nos nossos principais objectos de estudo ${ }^{17}$. Mas, na medida em que os indivíduos se inserem em determinados contextos, pensar António Luís Pereira permitirá compreender as principais características que se desenvolvem em torno do funcionamento de determinados grupos sociais como, por exemplo, o grupo dos homens de negócio ao qual ele pertencia.

As primeiras páginas, do primeiro Livro de Razão, estão preenchidas com "o gado ao ganho" que, a partir de 1837, António começou a espalhar pelos vários lugares da freguesia de Paderne e de outras freguesias do mesmo concelho de Melgaço ${ }^{18}$. Alguns bois, poucos cavalos, uma experiência com

${ }^{17}$ REVEL, Jacques - Prefácio..., cit., p. 19. Na opinião do autor, uma das novidades dos procedimentos da micro-história, verifica-se na capacidade que tem em inventar novos objectos de estudo.

${ }^{18} \mathrm{Na}$ medida em que esta actividade era considerada ilícita pelas Ordenações (Quarto Livro, Título LXIX), dificilmente se poderá encontrar, em Portugal, documentação oficial sobre este tipo de negócio apesar de ter sido muito praticado entre nós como também foi em vários países da Europa, ao longo do Antigo Regime. No Minho, o negócio do "gado ao 
cabras que parece não ter resultado e muitos porcos, é, em síntese, aquilo que podemos encontrar nos primeiros registos relativos a este negócio. Enquanto os bois e os cavalos se destinavam à venda nas feiras de gado da região, os porcos eram entregues para engorda durante um ano, no final do qual ele recebia metade da carne ou os presuntos. Nestas primeiras páginas, as referências à compra de porcos, ao seu preço, em casa de quem estavam e quantas arrobas de carne tinham rendido, são as informações que mais chamam a atenção. De 1837 para o ano de 1838 comprou 16 porcos que colocou, pelas condições já indicadas, a engordar em casa de várias vizinhas - os nomes indicados nestes contratos são sempre de mulheres, porque a criação de porcos pertence à economia doméstica da casa camponesa e, por isso, é uma das tarefas que concerne às mulheres.

Aqui e ali aparecem os empréstimos de dinheiro a juros. Apesar de se tratar de pequenas quantias, o nosso negociante não deixa de tomar algumas precauções exigindo garantias: fiadores ou hipotecas. É um negócio que parece dar os primeiros passos. Para cada empréstimo, além de anotar o nome e a morada do devedor e a garantia dada, ano após ano vai registando o pagamento dos juros e o abatimento do capital até à total liquidação da divida ou à sua transferência para outro responsável. Em todos os empréstimos pode verificar-se que o pagamento dos juros se prolonga por alguns anos e nem sempre é feito em dinheiro. Por vezes, tanto os juros como o capital da dívida eram abatidos com produtos agrícolas como, por exemplo, o milho ${ }^{19}$.

Mas o conteúdo mais significativo deste primeiro Livro de Razão é, sem dúvida, a compra e arrendamento de terras. Por isso, centremo-nos, por ora, nesta rubrica. A partir da página 14 surgem as primeiras referências

\footnotetext{
ganho" sobreviveu até ao século XX, sendo praticado através de contratos orais. Por isso, não possuímos estudos que nos permitam avaliar a importância e a extensão que esta forma de criação de gado atingiu no nosso país. Sobre "o gado ao ganho" cf. MORICEAU, Jean-Marc - L'Èlevage sous L'Ancien Règime (XVIe - XVIIIe siècles). Paris: SEDES, 1999, p. 15-30; DEMONET, Michel - Tableau de l'Agriculture Française au milieu du $19^{e}$ siècle. L'enquête de 1852. Paris: EHESS, 1990, p. 97-99; ANTOINE, Annie, BOEHLER, Jean-Michel, BRUMONT, Francis - L'Agriculture en Europe Occidentale, à l'époque moderne. Paris: Belin, 2000, p. 172-173.

19 APFP, Livro de Razão no 1, fol. 29. Em 5 de Julho de 1840 anotou que tinha "de José Luís Lourenço e mulher, do lugar do Pinheiro, uma escritura feita na nota de Almeida de Melgaço pelo empréstimo de 144.760rs a juro". E acrescentou: "os juros que paga são 24 alq. de milho cada anno segundo o nosso contrato".
} 
à compra de terras. Pelas datas indicadas, as compras tinham começado antes da aquisição do Livro e do início da sua redacção. Por isso, o nosso negociante, almejando fazer uma boa gestão do seu património iniciou os assentos das compras de terras com os prédios rústicos que tinham sido adquiridos em 1835.

Primeiro foi a terra da Pocinha, à qual se seguiu, em 1836, os Balados da Ponte da Lage. Em Janeiro de 1837, comprou a Coutada da Abelenda, em Agosto do mesmo ano, o Pelo Grande da Abelenda e no mês seguinte, Setembro, o Pelo Pequeno da Abelenda. Em Janeiro de 1838, negociou outro "bocado" de terra da Pocinha e em 16 de Maio adquiriu mais um bocado de terra junto da Ponte da Lage, denominado de Calçadinha. A 25 do mesmo mês, obteve outra terra da Pocinha e em Novembro do mesmo ano negociou a Casa dos Moinhos. A partir de então, António instalou-se, definitivamente, no lugar dos Moinhos, de onde passaria a desenvolver os seus negócios.

Quadro nº 1 - Compras de imóveis de António Luís Pereira (1835-1845)

\begin{tabular}{|c|c|c|c|c|}
\hline Data & $\begin{array}{c}\text { Nome da } \\
\text { propriedade }\end{array}$ & \begin{tabular}{|c} 
Valor da \\
Compra em rs
\end{tabular} & Renda & $\begin{array}{l}\text { Situação da } \\
\text { propriedade }\end{array}$ \\
\hline $25 / 04 / 1835$ & Campo da Pocinha & 71.890 & 10 alq. & Hipotecada/1840 \\
\hline $26 / 12 / 1836$ & Valados da P. Lage & 24.500 & 12 alq. & Hipotecada/1840 \\
\hline $16 / 01 / 1837$ & Coutada d'Abelenda & 29.000 & & Hipotecada/1840 \\
\hline $13 / 08 / 1837$ & Pêlo G. d'Abelenda & 40.000 & & Hipotecada/1840 \\
\hline $09 / 09 / 1837$ & Pêlo P. d'Abelenda & 25.000 & 1,5alq./milho & \\
\hline $16 / 01 / 1838$ & Campo da Pocinha & 12.000 & 14 alq./milho & \\
\hline $16 / 05 / 1838$ & Campo Calçadinha & 45.160 & $1 / 4$ de feijão & \\
\hline $25 / 05 / 1838$ & Campo da Pocinha & 26.000 & & \\
\hline $17 / 11 / 1838$ & Casa dos Moinhos & 54.000 & & \\
\hline $09 / 06 / 1839$ & $\begin{array}{c}\text { Propriedade de } \\
\text { Barreiros }\end{array}$ & 245.000 & $\begin{array}{l}\text { 16alq./milho } \\
\text { 0,5alq./feijão }\end{array}$ & $\begin{array}{c}\text { Hipotecada } \\
1840 / 1841\end{array}$ \\
\hline $09 / 07 / 1839$ & Coutada da Portinha & 43.000 & $2.000 \mathrm{rs}$ & Hipotecada/1840 \\
\hline $16 / 08 / 1843$ & Moinho da Lage & 95.000 & "a meias" & \\
\hline $25 / 08 / 1844$ & O Souto & 24.000 & & \\
\hline $27 / 11 / 1844$ & Casa do Granjão & 15.000 & 100rs/mês & \\
\hline $08 / 07 / 1845$ & Casa dos Moinhos & 27.000 & & \\
\hline $27 / 04 / 1845$ & Rocio/C. da Cruz & 68.000 & $\begin{array}{l}\text { 7alq./milho } \\
1 / 4 \text { de feijão }\end{array}$ & \\
\hline $20 / 07 / 1845$ & Canastro e Eira & 20.750 & & \\
\hline $30 / 12 / 1845$ & Campo o Bal & 16.500 & 2 alq. & \\
\hline $\begin{array}{c}\text { Total } \\
\text { Compras } \\
\text { e Rendas }\end{array}$ & & 881.300 & $\begin{array}{l}\text { Milho/62,5alq. } \\
\text { Feijão/1 alq. } \\
1.200 \mathrm{rs}\end{array}$ & \\
\hline
\end{tabular}

Fonte: A.P.F.P.: Livro de Razão $n^{0}$ 1, fol. 14 a 17, 24 a 25v, 35 a 36, 39v a 41, 45 a 45v. 
Além de registar o nome pelo qual as propriedades eram conhecidas e a data da sua aquisição, o negociante, cuidadoso com a gestão dos seus bens, não se esqueceu de nos indicar o nome do antigo proprietário, o preço pelo qual fez a compra, as despesas com as escrituras e sisas, bem como o montante pelo qual estas propriedades foram arrendadas. António era negociante. Investia em terras, mas não as trabalhava. Só o "vinho" fugia a este modelo de exploração! O "vinho", como ele designava a exploração das vinhas, ficava por sua conta ou, pertencia "à casa", raramente arrendando a exploração das vinhas. Quanto ao resto, após a aquisição das terras, entregava-as a lavradores da freguesia - frequentemente ao antigo proprietário - em troca de uma renda composta essencialmente de cereais (milho) e feijão.

Mas as aquisições não tinham cessado. Em 1839, o negociante fez uma das suas maiores aquisições ao comprar o Pelo da Calçadinha e a Propriedade de Barreiros "por arrematação em haste publica". Depois desta compra, na qual parece ter despendido uma grossa quantia em dinheiro, só voltaria a fazer nova aquisição em 1843, quando comprou um moinho junto da Ponte da Lage que arrendou "a meias" a uma moleira. A compra de bens imóveis parece ter finalizado em 1845 quando adquiriu uma outra casa, no mesmo lugar dos Moinhos, "com seu rocio, o Campo da Cruz", além de um canastro, uma eira e mais outro pedaço de terra, designada de Campo do Bal.

Como se pode observar pela síntese apresentada no quadro $\mathrm{n}^{0} 1$, o jovem negociante, que se tinha instalado na aldeia com uma loja, transformou-se, apenas numa década, num proprietário fundiário relativamente abastado se considerarmos que estava sediado numa região que é um dos bastiões do minifúndio minhoto. Com a aquisição de terras de distinta qualidade e diferentes áreas (coutadas, leiras, pêlos, campos, campinhos e soutos), com a compra de casas, de um moinho, de uma eira e um canastro, António tinha conseguido formar uma verdadeira exploração agrícola que lhe permitiria assegurar o sustento de uma família, mas, sobretudo abastecer a sua loja com produtos agrícolas originários da região: milho, feijão e vinho.

Todavia, a sua verdadeira vocação era o negócio. Para o desenvolver, em Junho de 1839, resolveu tomar por "emprazamento de 3 vidas" umas casas no lugar da Portela com o seu alpendre e lagar de azeite "que tudo 
era de Simão Pereira da Brejoeira [...] por oito mil reis de foro cada ano". No entanto, no dia 13 de Agosto do mesmo ano, António arrendou esta "venda" a outro negociante, Manuel Caetano Ribeiro, por moeda e meia cada ano (7.200rs) "com a condição de serem para [ele] todos os estrumes que fizer na corte da dita casa, e vender [o seu] vinho em primeiro lugar" ${ }^{20}$.

Neste Livro de Razão, ainda podemos encontrar os assentos de outros negócios ou experiências que empreendeu, mas que foram abandonadas logo que detectou que não tinham a rentabilidade que ambicionava. Por exemplo, em 1847, anota uma "lembrança de linho que junta e vai para casa". Recebera o linho em "pares" que depois foram transformados em "afuzais". Nesse ano, tendo recebido, 223 "pares" que renderam 9 "afuzais" apontou que se tratava de "fraco negócio"21. Todavia, pensamos que estamos perante mais uma forma de pagamento habitual nos meios rurais onde predominava a economia de subsistência. A produção de linho era outra das fontes de rendimento da pequena economia agrária. Semeado, colhido e tratado pela mão-de-obra feminina, o linho transformava-se em moeda de troca na aquisição de outros géneros necessários ao bem-estar da família camponesa. Além disso, o linho era uma das principais matérias-primas na preparação dos enxovais e na confecção de peças de vestuário como, por exemplo, as camisas e os saiotes "representando praticamente metade do consumo total de têxteis" "22. Daí o interesse de qualquer negociante em possuir na sua loja linho para venda. Em cabelo, fiado ou tecido, o linho era um produto de consumo generalizado quer nos meios rurais quer nas cidades e, por isso, com grande interesse comercial. Estando as sociedades rurais privadas de meios monetários, os lavradores pagavam a compra dos produtos de que necessitavam com os géneros que retiravam das suas explorações agrícolas. Por sua vez, os comerciantes, instalados nestes meios, atribuíamlhes um valor e recebiam-nos como pagamento dos produtos que vendiam,

${ }^{20}$ APFP, Livro de Razão n ${ }^{\circ}$ 1, fol. 26 e 27.

${ }^{21}$ APFP, Livro de Razão no 1 , fol. 94v e 95.

${ }^{22}$ MADUREIRA, Nuno Luís - Lisboa. Luxo e Distinção (1750-1830). Lisboa, 1990, p. 72; DURÃES, Margarida - Herança e Sucessão. Leis, Práticas e Costumes no termo de Braga (sécs. XVIII - XIX). Tese de Doutoramento, Univ. do Minho, 2000, p. 218-231; JUSTINO, David - A Formação do Espaço..., cit. p. 161. 
voltando a colocá-los no mercado de forma a obterem uma mais-valia ${ }^{23}$. Se o negócio do linho fora "fraco" devia-se, certamente, à inexperiência de António que sobreavaliou os "pares" de linho na expectativa que rendessem mais "afuzais". Será que continuou a aceitar os "pares" de linho como forma de pagamento das compras que os clientes faziam na sua loja? Nada nos permite afirmar essa possibilidade porque nunca mais voltamos a encontrar qualquer apontamento sobre este tipo de negócio nos Livros de Razão.

A análise destas e de outras informações, veiculadas pelo $1^{\circ}$ Livro, despertou-nos o interesse em saber mais sobre este indivíduo que desde o começo da nossa observação se revelou extremamente habilidoso para os negócios, arrojado, de uma lucidez invulgar em relação aos negócios que the eram mais vantajosos, correndo riscos sem descurar a máxima precaução.

Afinal, quem era António Luís Pereira? A que família pertencia? A uma família de comerciantes? Como e onde tinha ele aprendido a arte de fazer negócios?

O que se sabe da sua vida, até ao dia em que ele sentiu necessidade de organizar contabilisticamente os seus negócios nos Livros de Razão que passou a possuir, está quase inteiramente contido nos registos paroquiais e nos arquivos notariais havendo, no entanto, muitos aspectos do seu percurso de vida e da sua actividade que continuam na sombra.

\section{Sob o lema "é preciso dinheiro para fazer dinheiro"}

António era natural da freguesia de Paço Vedro de Magalhães, do concelho de Ponte da Barca $^{24}$. Nascido em 1812, era o primeiro filho do casamento de André Bento Pereira, natural da mesma freguesia, com Maria

${ }^{23}$ CAPELA, José Viriato Eiras - O porto de Viana no contexto do comércio externo português (análise à balança comercial de 1781) in Viana - o mar e o porto, Viana do Castelo, 1987, p. 94; Cf. ainda, DURÃES, Margarida - Une population qui bouge: Les migrations temporaires et saisonnières à partir de Viana do Castelo (XVIIIe - XIXe siècles). Obradoiro de História Moderna. 15 (2006) 69-75.

${ }^{24}$ Arquivo Distrital de Viana do Castelo (ADVC), Registo Paroquial, Livro de Nascimentos (1851-1866), da freguesia de Paderne, concelho de Melgaço, fol. 11. 
Teresa de Oliveira, natural da freguesia de Adaúfe, do concelho de Braga, realizado em 16 de Julho de $1809^{25}$.

Não conhecemos a data exacta nem as razões que levaram esta família a abandonar a freguesia de Paço Vedro de Magalhães e a região de Ponte da Barca para se instalar no concelho de Valadares ${ }^{26}$. As últimas informações que obtivemos na região de Ponte da Barca datam de 1820 e referem-se ao nascimento e baptizado de Rosália Teresa, terceira filha de André Bento e Maria Teresa ${ }^{27}$. Depois desta data, os nomes dos pais de António desaparecem dos registos da paróquia de Paço Vedro.

Em razão do exposto não podemos deixar de apontar os fortes indícios que nos alertaram para a tradição migratória que parecia viver-se no seio desta família. Em primeiro lugar, aquando do nascimento de António ficamos a saber que os seus avós maternos e a sua mãe Maria Teresa eram originários da freguesia de Adaúfe, concelho de Braga. Em sentido contrário ao das históricas migrações minhotas ${ }^{28}$, esta família tinha optado por Ponte da Barca, região que se situa a norte de Braga. Em segundo lugar, o prolongado espaçamento existente entre os nascimentos do segundo e terceiro filho do casal - Francisco José, segundo filho do casal nascido a 12 de Novembro de 1814, era 6 anos mais velho do que sua irmã Rosália Teresa - chamaram a nossa atenção, já que é um dos indicadores que permite suspeitar da existência de ausências continuadas e habituais de André Bento. Estaremos perante mais um dos muitos lavradores minhotos que necessitavam de partir periodicamente "ao ganho" para complementarem o magro rendimento que

${ }^{25}$ ADVC, Registo paroquial. Livro de Nascimentos (1777-1854), da freguesia de Paço Vedro de Magalhães, concelho de Ponte da Barca, fol.140v e Livro de Casamentos (1748-1853), da freguesia de Paço Vedro de Magalhães, concelho de Ponte da Barca, fol.176v.

${ }^{26} \mathrm{O}$ concelho de Valadares foi extinto pelo decreto de 24 de Outubro de 1855 . Até então integrava várias freguesias que foram distribuídas pelos concelhos de Monção e Melgaço. A freguesia de Paderne que integrava o concelho de Valadares ficou a pertencer a Melgaço depois da extinção daquele concelho.

${ }^{27}$ ADVC, Registo paroquial. Livro de Nascimentos (1777-1854) da freguesia de Paço Vedro de Magalhães, concelho de Ponte da Barca, fol. 168v.

${ }^{28}$ SAMPAIO, Alberto - Estudos Históricos e Económicos. Porto, Livraria Chardon, 1923, p. 176-178. 
conseguiam retirar das suas pequenas explorações agrícolas e, desse modo, sustentarem a família ${ }^{29}$ ?

A partir de um determinado momento - que ainda não conseguimos datar -, André Bento terá resolvido partir de novo. Porém, desta vez, a família acompanhou-o. Seguindo a tradição familiar, optaram por rumar ainda mais para norte, estabelecendo-se no concelho de Valadares, junto da fronteira com a Galiza. Também aqui a família de António continuará a ser registada, na documentação consultada, como se tratando de lavradores. Porém, graças a um pequeno apontamento que António inseriu no seu livro quando, em 1835, adquiriu a primeira "terra da Pocinha", ficamos a saber que o pai, além de lavrador executava trabalhos de pedraria. Comprada a leira e havendo necessidade de fazer algumas obras de beneficiação, António chamou o pai, a quem pagou o serviço de reparação dos muros como a qualquer outro pedreiro, apontando no seu livro as despesas que tinha efectuado com as reparações, nos seguintes termos: "por obras que meu Pai lhe fez que paguei $11 \$ 000$ rs" 30 .

Sendo António filho de pequenos lavradores que tinham necessidade de complementar os seus rendimentos com os ganhos que o chefe de família conseguia auferir trabalhando no sector da construção, como é que ele conseguiu o capital necessário para encetar a sua actividade de negociante?

A resposta foi-nos dada pela análise dos Livros de Notas dos Tabeliães do concelho de Valadares.

Em 26 de Novembro de 1840, quando António tinha à volta de 28 anos, teve de fazer uma escritura de "confissão de divida", facto que nos permitiu conhecer o seu benfeitor e principal financiador dos seus negócios ${ }^{31}$. Nessa escritura, o nosso negociante confessa que foi o padre Manuel José Gomes Vilarinho, reitor de uma paróquia vizinha que em "diferentes parcelas e ocazions lhe avia emprestado para arranjos de seu negocio e algumas

${ }^{29}$ DURÃES, Margarida - Espírito de aventura ou aperto da vida? As Migrações Internas e os seus Impactos na Organização Familiar e Social das Comunidades Rurais do Alto-Minho (sécs. XVIII-XIX). Estudos Regionais, $2^{\mathrm{a}}$ série, 3 (2009) 117 - 145.

${ }^{30}$ APFP, Livro de Razão no 1 , fol. 13v.

${ }^{31}$ Segundo o historiador Gérard Béaur, existem múltiplos laços entre as dívidas e o mercado fundiário, entre a circulação de terra e a circulação de dinheiro. Cf. BÉAUR, Gérard - Foncier et crédit dans les sociétés préindustrielles. Des liens solides ou des chaînes fragiles?. Annales H.S.C. 6 (1994) 1411-1428. 
compras de bens" várias quantias, das quais resultou, no momento da escritura, uma dívida de 200 mil réis. E como de momento, António não tinha dinheiro para pagar, não só confessava a dívida como garantia o seu pagamento com a hipoteca de alguns bens imóveis de que era proprietário ${ }^{32}$.

No ano seguinte, em 1841, encontramos o mesmo negociante a fazer nova confissão de dívida. Desta vez os credores pertenciam à firma José Vicente \& Companheiro, negociantes da vila de Monção. Pelo teor da escritura ficamos a saber que era desta firma que "a vários annos tinha trazido fazendas fiadas para sortimento de seu negocio", confessando estar a dever "por a justo de contas" a quantia de 191.460rs. Como também não tinha meios para inteira satisfação da quantia em dívida, António obrigava-se por seus bens a pagar o capital e os juros "em pagamentos iguais de dois em dois meses e cada hum de vinte e quatro mil réis athe emteira satisfação". Como garantia dava em hipoteca o seu campo do Soutilho e a sua propriedade de Barreiros ${ }^{33}$.

Com algum dinheiro emprestado e abastecendo o seu negócio a crédito, António tinha conseguido comprar vários bens fundiários que arrendava logo de seguida. Simultaneamente adquiria gado que colocava a engordar de modo a obter mais-valias na sua venda e emprestava dinheiro a juro. Com estas estratégias, o negociante conseguia rentabilizar ao máximo os capitais que the emprestavam assim como os créditos que obtinha dos seus fornecedores. $\mathrm{O}$ cruzamento da análise dos seus apontamentos contabilísticos com o conteúdo destas duas escrituras notariais sugere-nos que a principal estratégia comercial, utilizada por António e que está no cerne do seu êxito, era a que resultava da célebre expressão: "pagar com o pêlo do mesmo gato". Todas estas ilações podem ser confirmadas se nos ativermos ao rol das terras compradas e que, ao longo de vários anos, foram sendo hipotecadas como garantia de pedidos de empréstimos ou como garantia de dívidas contraídas na compra de produtos para abastecer a "venda" que possuía no lugar dos Moinhos. Nunca as perdeu! Nunca as hipotecas tiveram de ser activadas! Os lucros que ele obteve nos distintos negócios, foram suficientes para saldar os créditos e empréstimos quando chegava o momento de fazer os pagamentos.

\footnotetext{
fol. $3 \mathrm{v}-4$.

${ }^{33}$ ADVC, Arquivo Notarial. Julgado de Valadares, $2^{\circ}$ ofício. Cota, 5.1.2.54, fol. 71v-73v.
} 
Mas demoremo-nos um pouco mais na escritura de confissão de divida à firma José Vicente \& Companheiro. Ela representa um dos raros documentos que possuímos em relação ao negócio que se realizava na "venda". Por ela ficamos a saber que entre os vários produtos que ali eram vendidos estavam as fazendas ou panos adquiridos no armazém de Monção. E, pela quantia em dívida, António tinha um grande escoamento de produtos têxteis que não parece coadunar-se nem com o número de possíveis clientes da aldeia nem com a sua capacidade de consumo ${ }^{34}$. Mas, como em qualquer outra loja de aldeia o sortido teria de ser mais variado, já que os comerciantes rurais eram os principais intermediários e o elo de ligação entre o mundo rural e o mundo urbano. Das cidades e vilas vinham os produtos que as economias agrícolas de subsistência não produziam e, paralelamente, as mesmas cidades e vilas eram abastecidas pelos excedentes das economias rurais.

Não é difícil conhecer os produtos originários da região que António ajudava a escoar. Os cereais, milho e centeio, mas sobretudo o vinho e os presuntos, eram os principais produtos da região comercializados por este negociante. O milho era-lhe fornecido através dos arrendamentos das suas terras mas também era moeda de troca utilizada pelos camponeses nas compras que faziam na "venda" assim como servia para pagar os juros e as dívidas que contraíam junto do negociante. $\mathrm{O}$ vinho, como já antes referimos era proveniente das suas terras, sendo as vinhas exploradas directamente. Todavia, quando o seu vinho não chegava para o abastecimento da "venda", António adquiria uvas a outros proprietários como aconteceu no ano de 1847. Neste ano comprou "todas as uvas de Bento da Arroteia por 5.000rs e renderão 24 cestos". No ano seguinte, em 1848, colheu nas suas terras 105

\footnotetext{
${ }^{34}$ A importância dos têxteis, no sortido das lojas dos comerciantes rurais, já foi avaliada noutros estudos que se dedicaram à análise pormenorizada do papel desempenhado por estes agentes económicos no abastecimento das regiões rurais e no escoamento dos produtos originários da agricultura. Cf., além da bibliografia já apresentada, PRONOVOST, Claude - Marchands et crédit marchand au début du XIXe siècle in BOUCHARD, G. e GOY, J. (dir) - Famille, économie et société rurale en contexte d'urbanisation (17e-20 siècles). Actes du Colloque d'histoire comparée Québec-France. Chicoutini/Paris: SOREP/EHESS, 1990, p. 237-249; neste caso particular, não podemos deixar de notar a localização da loja. A proximidade da fronteira com a Galiza permitiria a António alargar a área dos seus negócios através dos circuitos legais e ilegais que neste período incrementaram o comércio entre as regiões fronteiriças. Ver sobre o assunto JUSTINO, David - A Formação do Espaço ..., cit. p. 215-218.
} 
cestos de uvas. Como não há qualquer referência a compras de uvas a outros lavradores, pensamos que neste ano conseguiu abastecer a "venda" com o vinho produzido nas suas próprias terras ${ }^{35}$. Por seu lado, o abastecimento de presuntos era feito através do sistema de negócio "do gado ao ganho" que, como já fizemos notar anteriormente, ele explorou desde os inícios da sua actividade de negociante.

Os produtos que vinham de fora eram, como já vimos, as fazendas mas, também, o sal e um conjunto muito variado de miudezas destinadas ao fabrico dos utensílios produzidos pelas pequenas oficinas artesanais da região. Como já antes sugerimos, as referências ao movimento comercial da loja são escassas, surgindo aqui e ali de uma forma indirecta. Quase sempre, essas referências encontram-se relacionadas com os títulos de dívida que eram aceites e assinados pelos clientes. Quando os montantes das dívidas na loja atingiam valores elevados o seu pagamento era protelado. Então, António passava-as a títulos de dívida, cobrando-se de juros e pedindo garantias do seu pagamento.

Foi assim que António construiu uma verdadeira rede de negócios. Estes não eram independentes da posse de terras assim como estas não estavam apartadas da actividade das lojas que mantinha nos dois principais lugares da freguesia: Moinhos e Portela. Como proprietário fundiário, à exploração das suas terras que era feita em regime de arrendamento ele aliava a produção de vinho e a criação de gado. Juntamente com as terras arrendadas, os rendeiros recebiam algumas cabeças de gado compradas pelo comerciante e fornecidas segundo o sistema de "gado ao ganho"36. O "gado ao ganho" e o empréstimo de dinheiro - as principais informações que podem ser extraídas de todos os Livros de Razão que António nos legou - não eram mais do que um prolongamento das actividades anteriores. A maioria dos títulos de dívida referidos nos livros, e mesmo aqueles que foram transformados em escritura pública, eram assinados por clientes da

35 APFP, Livro de Razão ${ }^{\circ}$ 1, fol. 84.

36 MEIJIDE PARDO, António - Aspectos del Comercio Gallego de Exportacion a Portugal en el siglo XVIII in Actas de las I Jornadas de Metodologia Aplicada de las Ciencias Historicas, vol. III. História Moderna, S. de C., 1975, p. 803-823. Segundo o autor, desde o séc. XVIII que Portugal era abastecido legal e ilegalmente de gado e cereais provenientes da região galega. No séc. XIX o comércio de gado intensificou-se graças à alta dos preços verificada em Portugal. 
loja, onde aos débitos das compras de artigos se juntavam algumas quantias que tinham sido pedidas por empréstimo.

Através dos dados que conseguimos até agora reunir, é possível apreciar a amplitude do seu êxito e reconstituir os mecanismos essenciais que foram adoptados no caminho da sua ascensão social. Num complexo Deve-Haver, onde se inscrevem várias estratégias de negócio, António Luís Pereira passou, a pouco e pouco, de pequeno negociante devedor de somas avultadas aos fornecedores e ao seu protector, a proprietário rural e a "capitalista" que além de conceder empréstimos a juros financiava a criação de um número significativo de cabeças de gado bovino e cavalar.

Quando se inicia a década de cinquenta, o seu valor e prestígio já eram reconhecidos pelos seus pares, reunindo as condições para realizar o seu matrimónio no seio do grupo de que agora fazia parte. Em 1852, com 40 anos de idade, decide casar-se. Para esposa escolheu Francisca de Araújo, pertencente à família dos Sousas Vianas, comerciantes no lugar de S. Gregório, da freguesia de Cristóval ${ }^{37}$. Este casamento, realizado no seio do mesmo grupo socioprofissional, deve ter-lhe permitido não só a consolidação do seu lugar na rede de negócios da região mas também lhe deve ter aberto novos horizontes. No ano seguinte, a 9 de Maio de 1853, consolidou esta aliança tendo escolhido para padrinho de baptismo do seu filho primogénito, Manuel Policarpo, o Pe. Policarpo José de Araújo, irmão de Francisca.

\section{De eleitor a elegível}

Todavia, é nos recenseamentos eleitorais que o percurso de vida de António Luís Pereira melhor se visualiza, além de ser possível encontrar, nesta documentação, outras informações sobre as suas actividades que não foram contempladas nas fontes até agora utilizadas.

Com a implantação do regime liberal em Portugal deu-se início à produção dos recenseamentos ou listas eleitorais que tinham como principal

${ }^{37}$ ADVC, Registo Paroquial. Livro de Casamentos da freguesia de Cristóval (1827-1884), concelho de Melgaço, fol. 29. Cf. também, ESTEVES, Augusto César - O Meu Livro das Gerações de Melgacenses. Melgaço: Ed. A., 1989, p. 442. 
objectivo conhecer a população apta a participar nos actos eleitorais, através dos quais eram escolhidos os representantes dos cidadãos nos distintos órgãos da governação política e administrativa da nação. "Apesar de defensores da liberdade e da igualdade, os regimes liberais desenvolveram a sua filosofia política e social segundo critérios objectivos como a posse de propriedade fundiária, os rendimentos e a instrução de cada cidadão"38. Elaborados segundo a legislação eleitoral que foi promulgada, ao longo de todo o século XIX, pelos distintos parlamentos que governaram o país, os recenseamentos eleitorais estavam formatados segundo os dois pilares básicos da filosofia liberal - fortuna e instrução - em que assentava a edificação de todo o sistema político e consequentemente o funcionamento do aparelho do Estado ${ }^{39}$. Os sufrágios que davam origem às listas eleitorais eram voluntários e restritos. Os cidadãos, interessados em participar no acto eleitoral, deviam apresentar-se voluntariamente, munidos dos seus documentos a fim de provar as condições exigidas ao acto eleitoral, o qual permanecerá restrito ao longo do regime monárquico constitucional. Só alguns eram eleitores e muito poucos eram elegíveis. A participação no acto eleitoral era restrita aos cidadãos que declaravam um rendimento líquido anual de, pelo menos, 100 mil réis, enquanto era necessário um rendimento de 400 mil réis para se ser elegível ${ }^{40}$.

António sabia ler e escrever, como ficou comprovado no auto de abertura do $1^{\circ}$ Livro de Razão. Mas a sua idade, a qualidade de homem solteiro e a não posse de propriedade fundiária não lhe permitiam apresentar-se a sufrágio para participar nos actos eleitorais. O seu nome aparece nas listas eleitorais do concelho de Melgaço, pela primeira vez, em 1844, quando já tinha 32 anos de idade ${ }^{41}$. Continuava solteiro mas, agora, era proprietário. Por essa

${ }^{38}$ DURÃES, Margarida - Entrelaçando a teia Política. Profissões e rendimentos dos chefes de família nos recenseamentos eleitorais (Braga, 1851). Noroeste. Revista de História 3 (2007) 587.

${ }^{39}$ ALMEIDA, Pedro Tavares de (org.) - Legislação Eleitoral Portuguesa, 1820-1926. Lisboa: Imp. Nacional, Casa da Moeda, 1998.

${ }^{40}$ VARGUES, Isabel Nobre e RIBEIRO, M. Manuela Tavares - Estruturas políticas: parlamento, eleições, partidos políticos e maçonarias in MATTOSO, José (dir) - História de Portugal. Lisboa: Círculo de Leitores, vol. V, p. 191-198.

${ }^{41}$ Arquivo Municipal da Câmara de Melgaço, Listas dos recenseamentos eleitorais do Concelho de Melgaço (1844-1920). 
razão, declarou, para preenchimento da rubrica correspondente à "décima predial", a quantia de 2.400rs. A partir de então, o seu nome passou a constar nas listas anuais do concelho, sendo possível observar a evolução dos seus rendimentos e a sua correspondente proveniência. Em 1848, quando já tinha adquirido a maioria dos seus haveres, a verba correspondente à décima predial aumentou para 3.200rs, passando a preencher, também, a rubrica correspondente à "décima dos vencimentos" com 600rs. No ano seguinte, os montantes declarados em cada uma destas rubricas subiram para 4.000rs e 800 rs respectivamente.

Quadro nº 2 - Montantes das contribuições pagas por António Luís Pereira

\begin{tabular}{|c|c|c|c|c|}
\hline Data & Idade & Estado & Profissão & Total da Contribuição \\
\hline 1844 & 32 & solteiro & negociante & $2.400 \mathrm{rs}$ \\
\hline 1848 & 36 & solteiro & negociante e escrivão da Paz & $3.800 \mathrm{rs}$ \\
\hline 1852 & 40 & casado & negociante e escrivão da Paz & $4.800 \mathrm{rs}$ \\
\hline 1856 & 44 & "") & negociante e escrivão da Paz & $4.800 \mathrm{rs}$ \\
\hline 1860 & 48 & "" & negociante & $7.792 \mathrm{rs}$ \\
\hline 1868 & 53 & "") & negociante & $8.280 \mathrm{rs}$ \\
\hline 1878 & 66 & "" & negociante & $33.935 \mathrm{rs}$ \\
\hline 1882 & 70 & "'" & negociante & $36.240 \mathrm{rs}$ \\
\hline 1886 & 74 & " "' & negociante & 41.743rs \\
\hline 1887 & 75 & “" & negociante & 146.078rs \\
\hline
\end{tabular}

Fonte: A.M.C.M.: Listas dos recenseamentos eleitorais do Concelho de Melgaço (1844-1887).

Graças às informações veiculadas pelas listas eleitorais ficamos a saber que António, além de negociante e proprietário, tinha sido nomeado escrivão do juiz de paz da freguesia de Paderne auferindo a remuneração correspondente à de um funcionário administrativo judicial ${ }^{42}$. Foi o domínio da escrita, competência rara que só alguns detinham naquela época, que lhe permitiu assumir estas funções. Embora "ser um elemento da população, que conhece os modos de vida, os problemas, as dificuldades da vida dos restantes membros da comunidade" também possa ter contribuído para tal nomeação ${ }^{43}$. Detendo o cargo de escrivão, os rendimentos aumentaram e com eles teria acumulado prestígio e reconhecimento, acabando por ser declarado elegível para “jurado". As funções de escrivão da paz teriam sido

${ }^{42}$ Sobre o funcionamento e competências dos Juízos de Paz cf. CARVALHO, José Alberto B. S. de - Tensões numa Comunidade Rural do Baixo Minho. Adaúfe e o seu Juizo de Paz (1835-1880). Tese de Mestrado. Univ. do Minho, 1993, p. 74-91.

${ }^{43}$ Id., ibid., p. 97. 
abandonadas em 1857/58, já que nessa época desapareceram as referências relacionadas com o cargo.

Em 1860, aos 48 anos de idade, pela décima predial e dinheiro a juros, ficou registada a quantia de 7.792rs à qual se acrescentou 710rs pela côngrua e primícias. Continuava a ser elegível e, a partir de então, passou a ser apontado como um dos "40 maiores contribuintes" do concelho de Melgaço. Como se pode observar pelo quadro ${ }^{\circ} 2$, em 1878, aos 66 anos de idade, verificou-se uma extraordinária subida dos montantes declarados para pagamento dos impostos. Na "décima predial" o montante registado é de 13.195rs enquanto nos "diversos" foi lançada a verba de 20.740rs. Em 1887, quando António já tinha 75 anos de idade, os montantes declarados registaram um novo aumento, repartindo-se pelas várias rubricas das contribuições, do seguinte modo: décima predial, 52.410rs; décima industrial, 16.485rs; rendas de casas, 7.681rs; décima de juros, 69.502rs. A estes montantes juntava-se uma nota onde se declarava que António era elegível para o exercício de "cargos administrativos".

A imagem do percurso contributivo de António, explanada nas listas dos recenseamentos eleitorais, reflecte, sem dúvida, o seu sucesso não só no mundo dos negócios mas também espelha o reconhecimento que conquistou na comunidade em que estava inserido ao ser apontada a sua capacidade para participar na vida política através do exercício de cargos administrativos. Não o fez! Mas o legado ficou para os seus descendentes.

Faleceu em 1895, com 84 anos de idade, "na sua casa de morada do lugar dos Moinhos (...)". Segundo reza o assento de óbito, "não fez testamento, deixou filhos" e "foi sepultado no adro desta Igreja" 44 .

Em síntese: devemos acrescentar que os registos esparsos e confusos do $1^{\circ}$ Livro de Razão terminam em 1855. Entre esta data e 1869 não temos qualquer anotação ou registo dos negócios desenvolvidos por António. A partir de então, seguem-se 8 Livros de Razão que não só são de maior dimensão como adoptam uma nova metodologia, consubstanciada nos seguintes aspectos:

${ }^{44}$ Conservatória do Registo Civil do Concelho de Melgaço. Livro de Óbitos da freguesia de Paderne. Assento nº 20, ano de 1895. 
- em primeiro lugar, os diferentes ramos de negócio ou de investimentos foram separados devido ao grande incremento que cada um deles registou a partir daquela data. O "gado ao ganho" teria atingido tal dimensão que passou a merecer um livro próprio, aparecendo a partir de agora separado dos empréstimos de dinheiro a juros;

- em segundo lugar, é de notar que à actividade creditícia - esta regista um tal movimento que parece estar-se perante um pequeno banco rural junta-se a partir de 1869, o negócio de câmbio ou a compra e venda de moeda espanhola que alimentava as redes de comércio da região com a vizinha Galiza. Trata-se de um novo ramo de negócio. No início surge timidamente mas, no final do período a que se reportam os Livros de Razão, o negócio do câmbio irá prevalecer sobre todos os outros. É a época em que os negócios já contavam com a colaboração de Francisco José Pereira, filho e sucessor de António. Aquele conhecia e sabia utilizar alguns elementos da moderna contabilidade como "as partidas dobradas", que reforçam não só a imagem de um comerciante actualizado, como também a necessidade de possuir uma contabilidade ordenada e metódica devido ao incremento e desenvolvimento do negócio do dinheiro.

No entanto, algumas anotações de carácter familiar persistem em aparecer nas margens da contabilidade, reenviando-nos constantemente para outros níveis de pesquisa onde o enfoque da análise deixa de se centrar no indivíduo para privilegiar a avaliação das estratégias do grupo familiar e das redes sociais em que estas personagens se inseriam.

Este ensaio, circunscrito à narração da história de vida de António, acabou por nos conduzir à necessidade de elaborar análises particularizadas no âmbito dos dois ramos de negócio - "gado ao ganho" e empréstimo de dinheiro a juro - mas, também, desenvolver os estudos em torno das estratégias familiares de modo a conhecer como António utilizou e transmitiu aos seus descendentes o êxito económico e o reconhecimento e prestígio conquistados ao longo do seu percurso de vida. Uns e outros ficarão para uma próxima oportunidade ...! 